\title{
The Impact of IFRS Adoption on the Value Relevance of Accounting Information: Evidence from the Insurance Sector
}

\author{
Ali A. Alnodel ${ }^{1}$ \\ ${ }^{1}$ Accounting Department, Qassim University, Al-Mulida, Kingdom of Saudi Arabia \\ Correspondence: Ali A. Alnodel, P.O. Box 4667, Buraidah 51412 Qassim, Kingdom of Saudi Arabia. E-mail: \\ nodl@qu.edu.sa
}

Received: January 29, 2018

Accepted: February 20, 2018

Online Published: March 18, 2018

doi:10.5539/ijbm.v13n4p138

URL: https://doi.org/10.5539/ijbm.v13n4p138

\begin{abstract}
This paper aims to investigate whether the adoption of International Financial Reporting Standards (IFRS) increases the value relevance of accounting information for insurance firms listed in the Saudi stock market. The study employs the Ohlson model (1995) and the Easton-Harris valuation model (1991) in order to examine the association among stock market value and book value and earnings per share. The data was collected for 21 insurance companies listed in the Saudi stock market during the period 2007-2014, which covered pre- / post-IFRS periods. The results reveal that the book value of equity becomes less value relevant whereas earnings are more value relevant. Further analysis suggests that the increase in the value relevance of accounting information is positively influenced by companies' attributes, especially profitability and size rather than IFRS adoption. These results highlight the importance of institutional factors in the determination of the value relevance of accounting information in emerging stock markets. These results also expand IFRS research through a consideration of the insurance industry, which is more vulnerable to the accounting evaluation model.
\end{abstract}

Keywords: book value, earnings, firm size, IFRSs, insurance firms, profitability, value relevance

\section{Introduction}

Questions regarding the relevancy and reliability of accounting information continue to persist. Accounting information is considered to be more relevant when it creates a difference in the decisions made by users and to be more reliable when it is materially accurate and faithfully represents the phenomena that it claims to represent. The relevancy of accounting information has been recently boosted by the widespread adoption of International Financial Reporting Standards (IFRS). One of the most common assertions regarding IFRS is that this set of accounting standards is market oriented (Tarca, 2012) and fosters fair value principles. Therefore, the adoption of IFRS can cause a significant impact on the value relevance of accounting information (Bartov, Goldberg, \& Kim, 2005). This is especially important for insurance companies in which most of their assets and liabilities are close to their fair value (Nissim, 2010). Previous studies have produced mixed results with respect to the impact of the adoption of IFRS. This may be due to the environment and structure of the industry, market, and economy, which includes the type of the industry, legal environment, advancement of the business, education, or the development of the economy. This study extends these efforts through an examination of the value relevance of accounting information before and after the mandatory adoption of IFRS by Saudi insurance companies.

The study employs the return and price models to estimate the value relevance of earnings and equity information with their relationship to share prices. The Ohlson model (1995) and the Easton-Harris valuation model (1991) have been utilized to examine the association among stock market values, book value, and earnings per share. The data covers pre-IFRS and post-IFRS periods during 2007-2014. The study sample consists of 21 insurance companies listed in Saudi Arabia's stock market.

This study contributes to the literature in the following ways. First, it expands the previous research by focusing on the insurance industry, which is more vulnerable to the accounting evaluation model. The study also highlights the manner in which investment decisions are made in one of the emerging economies that has not received sufficient research efforts. The results of this study can also help in the evaluation of the consequences of the adoption of IFRS in the Saudi stock market, as the country has recently adopted a plan to necessitate the adoption of IFRS by all other industries. 
The structure of the paper will be as follows. The following section presents the literature survey; section 3 discusses the research methodology; section 4 explains the empirical results; and the last section presents the conclusion and some policy suggestions.

\section{Literature Review}

The literature pertaining to the value relevance of accounting information is relatively extensive and has been approached from different angles. The study conducted by Ball and Brown (1968) is one of the earliest comprehensive study investigating the association between unexpected earning and abnormal stock returns. Thereafter, a significant body of research has been conducted in the context of different markets (e.g., Amir, Harris, \&Venuti, 1993; Collins, Maydew, \& Weiss, 1997; Holthausena \& Watts, 2001; Brimble \& Hodgson, 2007; Soderstrom \& Sun, 2007). Holthausena and Watts (2001) classified the studies relating to value relevance into three sub-classes: 'relative association studies', 'incremental association studies', and 'marginal information content studies'.

From the changes and settings of accounting standards point, Amir et al. (1993) were the pioneers who discussed the value relevance for the US versus the non-US GAAP accounting measures. Then, the literature has been extensively concerned with the changes in accounting standards and the value relevance of the information produced therein.

From the perspective of accounting standards, the adoption of IFRS is currently attracting extensive research. For example, Bartov et al. (2005) studied the listed companies in Frankfurt, NYSE, AMEX, NASDAQ, and LSE, covering the period 1998-2000. Their results revealed a high degree of value relevance among accounting numbers under IFRS versus the non-IFRS. Barth, Landsman, and Lang (2008), covering the period 1990-2003 for many countries, arrived at the same findings. Jeanjean and Stolowy (2008) examined the impact of the adoption of IFRS on earning quality. They selected the UK, France, and Australia as first-time IFRS adopters. They observed that after the adoption of IFRS, the prevalence of earning management did not reduce in the UK and Australian companies, whereas it was enhanced in the French companies. In their opinion, there are a number of institutional and management variables that play a significant role in setting the reporting features. They emphasized that there should be consistency in the institutional factors rather than in accounting standards. Halonen, Pavlovic, and Persson (2013) examined the value relevance of financial reporting and its impact on stock prices in Sweden after the introduction of the new IFRS in 2005. In order to measure the value relevance, they collected accounting data and stock prices between 2007-2010 and applied the Ohlson's model. It was concluded that value relevance increased when measured by book value and earnings per share and accounting data has a high ratio of variations in the stock price. Landsman, Maydewa, and Thornmock (2012) found that information content increased in countries where IFRS was mandatorily adopted in comparison with countries that adopted domestic standards. Further, they suggested that the information content is dependent on the degree of foreign investment and the minimization of the reporting lag. Clarkson, Hanna, Richardson, and Thompson (2011) investigated the impact of the adoption of IFRS for Europe and Australia with respect to the relevance of book value and earnings for equity valuation. They utilized the product of EPS and BVPS. Using the linear pricing model, their coefficient was statistically different from zero and the sign was negative. Callao, Jarne, and La' inez (2007) attempted to find the difference between IFRS and local standards in Spain. They observed that employing IFRS in Spain increased the difference between the book value and market value. Consequently, they argued that there was no improvement in value relevance.

In the context of emerging economies, a number of studies have discussed the adoption of IFRS and its impact. For example, Klimczak (2011) examined the impact of mandatory adoption of IFRS in Poland. He discovered that accounting information is valued higher in the pre- period than in the post-IFRS period. Kousenidis, Ladas, and Negakis (2010) investigated the impact of IFRS on Greek companies and reported that IFRS has a negative impact on the incremental information content of book value of equity for stock prices and a positive influence on the earnings' incremental content in the post-IFRS period. Chen, Chen, and Su (2001) analyzed the adoption in the Chinese stock exchange market, Benayed and Abaoud (2006) examined the adoption of IFRS in the Tunisian stock exchange, and Shamki and Rahman (2012) studied the value relevance of earnings and book value of equity for the Jordanian market.

This extensive research concerning the adoption of IFRS, however, does not provide any fixed results. For example, Shamki and Rahman (2012) examined the behavior of earning and book value in relation to value relevance in Jordan. They discovered that in the price model, on an individual basis, relevance increased, but at the aggregate level, book value became irrelevant. Conversely, in the return model, they found that earnings were more relevant at individual as well as the aggregate level, whereas the book value became less relevant. 
They further argued that earnings are more relevant than book value. Similarly, Benayed and Abaoud (2006) examined the behavior of the Tunisian stock market and concluded that corporate value is dependent upon their future performance, which is highly correlated with the accounting information. Chen et al. (2001), while discussing the Chinese stock market, included the book value of equity per share as a balance sheet parameter in addition to accounting earnings.

In the Saudi context, a number of studies discuss the adoption of IFRS by Saudi companies. However, most of these studies have concentrated on non-financial sectors and reported unsettled results concerning the direct impact of IFRS on accounting information in the Saudi market. For example, Nurunnabi (2017) investigated the difference between Saudi local accounting standards and IFRS and reported some differences, most of which related to the environment of the Saudi market. Alkhatani (2012) studied the relevance of IFRS in the Saudi context. He further reported an appropriateness of IFRS in the Saudi context and asserted the importance of certain changes to the real practices. Almotairy and Alsalman (2011) explored the changes facing the adoption of IFRS in Saudi. Alsuhaibani (2012) focused on telecommunication business in order to explore the likely effect of the adoption of IFRS. He expected similar impacts as seen in other environments that have adopted IFRS. Alnodel (2015) investigated the possible impact of the adoption of IFRS on market efficiency in the Saudi stock market and reported no impact of the IFRS adoption on market efficiency. Almotairy and Stainbank (2014) discussed the educational requirements for the adoption of IFRS. They reported a number of suggestions to improve the educational requirements in order to apply IFRS in the Saudi context. Alnodel (2016) examined the effect of the adoption of IFRS on the integration of capital market in the Gulf Cooperation Council (GCC) countries. He reported no significant impact of the adoption of IFRS on the integration of the GCC stock markets.

Form a general perspective concerning the value relevance of accounting information, there are also some studies that have investigated the value relevance of accounting information in the Saudi context (e.g., Alsalman, 2003; Al-Sehali \& Spear, 2004; Barrak, 2011). For example, Alsalman (2003) investigated the institutional factors that influenced value relevance of accounting information in the Saudi Arabia and Kuwait contexts. He observed a significant difference in the value relevance of accounting numbers between the two countries due to the differences in their institutional factors rather than in their accounting standards. He argued that when there are similarities in terms of environmental factors, differences in accounting standards will not result in a significant difference in the value relevance of accounting information. With respect to earning conservatism, he found that institutional factors influence attitude toward earnings conservatism, which suggests the importance of institutional factors in determining earnings conservatism. Accordingly, the study concluded that institutional factors could prevent the effective accomplishment of international harmonization of accounting standards due to their role in information dissemination.

Al-Sehali and Spear (2004) empirically examined the decision relevance and timeliness of accounting earnings in Saudi Arabia, covering the period between 1995 and 1999. They reported no significant impact of the publication of accounting earnings on the market assessment of future cash flows. However, their study reported that the publication of accounting earnings caused individual investors to revise their security holdings in case the firms reported profit. In terms of timeliness of accounting earnings, their study reported an association between earnings and security returns, which suggests that increasing the measurement interval significantly improves this association. They further argued that there is low incentive for managers in Saudi companies in the incorporation of economic loss on a timely basis into accounting earnings. Therefore, they concluded that positive and negative earnings might have differential implications for the timeliness of accounting earnings and the Saudi environmental constituents, which implies that the low demand for accounting information and the weak monitoring system are important in determining the reporting process in the Saudi context.

Barrak (2011) investigated whether the establishment of Saudi Organization of Certified Public Accountants (SOCPA) resulted in financial statement information being more value relevant over time. The sample of the study covered a period from 1993-2009 for 97 firms with a total number of 997 observations. The study reported that in the case of equity valuation, the book value was found significant in the price regressions for the whole period while earning levels and changes were not significantly related to stock returns for all the years. He also reported that earnings are not value-relevant in equity valuation for loss-making firms. Further, Barrak (2011) argued that in the Saudi context the accounting information has a value relevance but mostly in the early period of his sample. 


\section{Research Methodology}

\subsection{Model}

Accounting information will prove to be more relevant when it makes a difference in the decisions made by users and more reliable when it is materially accurate and faithfully represents the phenomena that it claims to represent. The degree of association between firm value and accounting numbers is a direct check of the validity and reliability of the accounting information (Chandrapala, 2013).

For the empirical analysis, two models have been selected in this study: the return model (Easton-Harris valuation model) and the price model (Ohlson and Feltham-Ohlson price model). Gjerde, Knivsflå, and Sættem (2011) stated that share price or share return describes the behavior of investors in reflecting the extent to which they trust the accounting information and the financial statements. Barth, Beaver, and Landsman (2001) emphasized that price and return approaches have their specific value when someone desires to estimate the parameters for value relevance. According to Easton and Sommers (2003), the price-based studies examine financial statements whereas the return-based studies inspect accounting figures.

Ota (2001) reviewed some of the theories and evidence associated with the value relevance studies in accounting. He adds that the theoretical foundation of both return and price models are the same. However, sometimes the results are not consistent, which remains unexplained. It is his opinion that issues concerned with the price model are stated as 'scale effects' and those relating to the return model are known as 'accounting recognition lag' and 'transitory earnings'. Ota (2001) recommended that researchers should use both models, and in this way, they can avoid ambiguous conclusions. In this study, both models have been utilized, as suggested by Ota (2001).

The Easton and Harris valuation Model (1991), generally known as return model, describes the relationship between stock returns and accounting earnings. Stock returns are dependent on earning levels and change in earnings; both were deflated by the stock price at the beginning of last year's annual report announcement month. The Easton and Harris valuation model (1991) has been employed to evaluate the annual variations in the information content of the accounting variables between the pre- and post-IFRS periods. In this study, the return model is given in the following manner:

$$
\mathrm{RET}_{\mathrm{jt}}=\alpha_{0}+\alpha_{1} \mathrm{EPS}_{\mathrm{jt}} / \mathrm{P}_{\mathrm{jt}-1}+\alpha_{2}\left(\mathrm{E}_{\mathrm{jt}}-\mathrm{E}_{\mathrm{jt}-1}\right) / \mathrm{P}_{\mathrm{jt}-1}+\mathrm{e}_{\mathrm{jt}}
$$

Where:

$\mathrm{RET}_{\mathrm{jt}}$ : annual return (including cash dividends) of firm $\mathrm{j}$, measured three months after the fiscal year end;

$\mathrm{EPS}_{\mathrm{jt}}$ : earnings per share, measured three months after the fiscal year end;

$\mathrm{E}_{\mathrm{jt}}-\mathrm{E}_{\mathrm{jt}-1}$ : change of annual earnings per share;

$\mathrm{P}_{\mathrm{jt}-1}$ : stock price at the beginning of last year's annual report announcement month;

$\Delta \mathrm{ET}=(\mathrm{Ejt}-\mathrm{Ejt}-1) / \mathrm{P}_{\mathrm{jt}-1}$

Whereas, $\mathrm{e}_{\mathrm{jt}}$ is the stochastic term; ${ }^{1} \alpha_{1}$ is a proxy for the statistical relationship between the stock price and book values of equity per share, and $\alpha_{2}$ measures the statistical relationship between stock prices and earnings per share (Easton 1999).

For the price model, this study uses Feltham and Ohlson's (1995) price model as a basic model to examine the value relevance of accounting information. The Ohlson's price model has been widely used across the literature. The model states that the value of a firm's equity is dependent on the book value and earnings. This model can be utilized to evaluate the overall value of equity, earnings, and stock prices pre- and post-IFRS periods. A modified Feltham-Ohlson's (1995) price model is presented in the manner given below:

$$
\mathrm{MV}_{\mathrm{jt}}=\beta_{0}+\beta_{1} B \mathrm{~V}_{\mathrm{jt}}+\beta_{2} \mathrm{EPS}_{\mathrm{jt}}+\mathrm{u}_{\mathrm{jt}}
$$

Where:

$\mathrm{MV}_{\mathrm{jt}}$ : market value per share of firm $\mathrm{j}$ at the end of the annual report announcement month;

$B V_{j t}$ : book value of equity per share of firm $j$ at year $t$;

EPS $\mathrm{jt}$ : reported fiscal year accounting earnings per share of firm $\mathrm{j}$;

whereas $\mathrm{u}_{\mathrm{jt}}$ is stochastic term.

\subsection{Hypotheses}

The basic objective of IFRS is to provide quality financial information to users regarding financial statements. It is assumed that value relevance of both earnings and book values of equity will increase after the implementation 
of IFRS. Keeping that in mind, the following hypotheses have been formulated:

Hypothesis 1: Accounting information is more value relevant in the post-IFRS period than in the pre-IFRS period.

Hayn (1995) and Collins et al. (1997) applied the return and the price models respectively and concluded that positive and negative earnings have impact on value relevance of accounting information. Accordingly, the next hypothesis has been formulated:

Hypothesis 2: Positive vs. negative earnings has an impact on value relevance of accounting information, regardless of the adoption of IFRS.

Collins et al. (1997) observed that the size of the firm also influences the value relevance of accounting information. In this study, the hypothesis has been formulated with reference to the subject of the study in the following way:

Hypothesis 3: Firm size has an impact on the value relevance of accounting information regardless of the adoption of IFRS.

\subsection{Data}

The dataset utilized in this study has been drawn from Gulfbase, which provides data for stock market in Saudi Arabia. A recheck of the data with the official website of stock market authorities (Capital Market AuthorityCMA and Tadawul) has also been carried out. The data covers pre- and post-IFRS adoption periods during 2007-2014.

Since the study attempts to compare the figures reported under the local accounting standards to the figures reported under IFRS, the data for both periods have been collected. In Saudi Arabia, insurance companies have mandatorily adopted IFRS in 2009. Therefore, a comparison of 2008 (pre-IFRS) with 2010 (post-IFRS) has been performed. The study sample consists of 21 insurance companies listed in the Saudi Arabian stock market. Table 1 presents the descriptive statistics of the variables used in the empirical analysis.

Table 1. Descriptive statistics

\begin{tabular}{|c|c|c|c|c|c|c|c|}
\hline & MV & RET. & BV & EPS & $E_{j t}-E_{j t-1}$ & $\Delta \mathrm{ET}$ & EPS/Pjt-1 \\
\hline \multicolumn{8}{|c|}{ (Entire sample): } \\
\hline Mean & 31.5499 & 18877.5 & 298970.6 & 0.0785 & 186.754 & 3937.6180 & -0.0027 \\
\hline Median & 25.5614 & 2360.50 & 200000.0 & 0.1100 & 71.285 & 2562.5000 & 0.006 \\
\hline Maximum & 161.1577 & 560116.0 & 1000000.0 & 7.5300 & 18297.710 & 1151051.0 & 0.1274 \\
\hline Minimum & 8.7358 & -590935.0 & 100000.0 & -5.9100 & -26677.240 & -910656.0 & -0.2150 \\
\hline Std. Dev. & 20.0570 & 112671.6 & 251551.3 & 1.7410 & 4373.261 & 148021.5 & 0.0583 \\
\hline \multicolumn{8}{|c|}{ Pre-IFRS (2008) } \\
\hline Mean & 17.4349 & 13129.47 & 221764.7 & -0.8512 & -1952.489 & -35417.47 & -0.0483 \\
\hline Median & 12.6828 & -14787.00 & 200000.0 & -0.9000 & -472.255 & -10098.00 & -0.0495 \\
\hline Maximum & 50.5379 & 67238.00 & 800000.0 & 0.6700 & 2000.462 & 23721.00 & 0.0382 \\
\hline Minimum & 9.0366 & -59207.00 & 100000.0 & -2.5100 & -26099.91 & -457593.00 & -0.1425 \\
\hline Std. Dev. & 10.2506 & 26835.22 & 181115.8 & 0.8543 & 6280.931 & 109665.50 & 0.0491 \\
\hline \multicolumn{8}{|c|}{ Post- IFRS (2010) } \\
\hline Mean & 24.1008 & 42595.6 & 285500.0 & 0.4480 & 689.905 & 20068.40 & 0.0185 \\
\hline Median & 18.9718 & 6566.5 & 200000.0 & 0.4350 & 378.450 & 8902.500 & 0.0193 \\
\hline Maximum & 52.4500 & 484912.0 & 1000000.0 & 4.8500 & 3980.238 & 188540.00 & 0.1075 \\
\hline Minimum & 8.7358 & -21043.0 & 100000.0 & -1.1400 & -546.370 & -7013.00 & -0.0595 \\
\hline Std. Dev. & 12.3970 & 117866.0 & 236898.3 & 1.3997 & 1167.998 & 44328.77 & 0.0471 \\
\hline
\end{tabular}

Notes. The sample consists of 21 firms listed in the Saudi Stock Markets with 136 firm year observations for the period 2007-2014. The variables' definitions are as follows. MV is the stock price of firm i at time t, measured three months after fiscal year end, while RET annual return (including cash dividends) of firm $\mathrm{j}$, measured three months after the fiscal year end; $B V_{j t}$ : book value of equity per share of firm $\mathrm{j}$ at year $\mathrm{t}, \mathrm{E}_{\mathrm{jt}}-\mathrm{E}_{\mathrm{jt} \mathrm{-1}}$ : change of annual earnings per share, $\mathrm{P}_{\mathrm{jt}-1}$ : stock price at the beginning of the last year's annual report announcement month $\Delta \mathrm{ET}=\left(\right.$ Ejt-Ejt-1) $/ \mathrm{P}_{\mathrm{jt}-1}$.

\section{Results}

This study has applied cross sectional regression to examine the value relevance of accounting information 
within the price and return models for Saudi Arabia, considering both the pre- and post-IFRS periods and considering the companies' attributes. These are described in the following subsections:

\subsection{Return and Price Models for Accounting Changes: Empirical Analysis}

The results of the regression estimations are depicted in Table 2. In cross-section regressions, the adjusted $\mathrm{R}^{2}$ has been used as the measure of value relevance. Table 2 presents the results of the Feltham and Ohlson's model (1995) and the results of the Easton and Harris model (1991) for the whole period (2007-2014) and for the pre-IFRS (2008) and the post-IFRS (2010) periods for companies where the change in IFRS has taken place.

It can be observed from Table 2 that the value of $\mathrm{R}^{2}$ decreased from 0.381 in the pre-IFRS adoption period to around 0.002 in the post-IFRS period. Earnings per share is significant in the pre-IFRS period, whereas it is insignificant in the post-IFRS period in the price model. In the return model, it is significant in both of the periods. Accordingly, the value relevance of accounting information for Saudi insurance companies has a downward movement and is falling in the post-IFRS period in price as well as in the return model, as observed from the values of $\mathrm{R}^{2}$. Following the Easton and Harris (1991) interpretation, Hypothesis 1 is partially rejected for Saudi insurance companies.

In general, the regression results of the two models indicate that the accounting information given in the financial statements is not value relevant for the investors in the Saudi stock market. Nonetheless, for investors, the earning per share is more value relevant than the change in earnings. These results support the findings of Callao et al. (2007), which reported that after the adoption of IFRS, there was no improvement in the relevance of accounting information due to the gap between book and market value.

One possible interpretation is that the insurance industry may be less affected by the IFRS adoption owing to the type of assets and liabilities that are always close to their fair value (Nissim, 2010), or due to the legal enforcement in the country that renders it difficult to realize the change. Daske, Hail, Leuz, and Verdi (2008) argued that in developing countries, there may be difficulties in realizing the outcomes of the IFRS adoption due to the nature of the capital market and the lack of legal enforcements.

Table 2. Price and return regression models for the change in accounting standards

\begin{tabular}{|c|c|c|c|}
\hline \multicolumn{4}{|c|}{ Model 1. Price Model (Dependent Variable MVjt): } \\
\hline \multicolumn{4}{|c|}{$M V_{j t}=\beta_{0}+\beta_{1} B V_{j t}+\beta_{2} E S_{j t}+u_{j t}$} \\
\hline & Pre-IFRS & Post-IFRS & $2007-2014$ \\
\hline & $(2008)$ & $(2010)$ & (Entire sample) \\
\hline BV & 0.00000195 & -0.00266 & -0.00293 \\
\hline EPS & $-23.59 * *$ & 350.7 & 306.6 \\
\hline Adj $R^{2}$ & 0.381 & 0.00218 & 0.00214 \\
\hline $\mathrm{F}$ & 4.608 & 0.154 & 0.123 \\
\hline Prob(F-stat) & $(0.000)$ & $(0.8575)$ & $(0.8580)$ \\
\hline \multicolumn{4}{|c|}{ Model 2: Return Regression Model (Dependent Variable RETjt): } \\
\hline \multicolumn{4}{|c|}{$\mathrm{RET}_{\mathrm{jt}}=\alpha_{0}+\alpha_{1} \mathrm{EPS}_{\mathrm{jt}} / \mathrm{P}_{\mathrm{jt}-1}+\alpha_{2}\left(\mathrm{E}_{\mathrm{jt}}-\mathrm{E}_{\mathrm{jt}-1}\right) / \mathrm{P}_{\mathrm{jt}-1}+\mathrm{e}_{\mathrm{jt}}$} \\
\hline & Pre-IFRS & Post- IFRS & $2007-2014$ \\
\hline & $(2008)$ & $(2010)$ & (Entire sample) \\
\hline EPS/Pjt-1 & $353253.6^{* * *}$ & $1137069.6^{* * *}$ & $1076457.3 * * *$ \\
\hline$\Delta \mathrm{ET}$ & $-1.902 * * *$ & $9.261 * * *$ & $12.06^{* * *}$ \\
\hline $\mathrm{R}^{2}$ & 0.767 & 0.572 & 0.640 \\
\hline $\mathrm{F}$ & 28.03 & 104.1 & 108.07 \\
\hline Prob(F-stat) & $(0.000)$ & $(0.000)$ & $(0.000)$ \\
\hline
\end{tabular}

Notes. $* * *$ and $* *$ are statistically significant at $1 \%$ and $5 \%$ respectively. The sample consists of 21 insurance firms listed in the Saudi Stock Exchange with 136 firm year observations for the period 2007-2011. The Variables' Definitions are presented in Table 1.

\subsection{Return and Price Models among Company Attributes}

Previous studies have reported that the value of accounting information is affected by the companies' attributes such as profitability and size (refer to Hayn, 1995 and Collins et al., 1997, for example). In the following sections, companies' attributes such as positive vs. negative earning and size will be examined to determine whether these attributes have any impact on the value relevance of accounting information, by using both price 
and return models for Saudi insurance companies pooled and year analysis. Here, concentration will be on years 2007 to 20014.

\subsubsection{Positive versus Negative Earnings}

A dummy variable $\left(D_{1}\right)$ has been used to test the second hypothesis. It is defined as one for negative earnings and zero for otherwise. Results are presented in Table 3 and 4.

In the price model, this dummy variable is insignificant in the post-IFRS period. Book value of equity is insignificant in the post- and pre-IFRS period; $\mathrm{R}^{2}$ shows less explanatory power in the post-IFRS period than in the pre-IFRS period. In price model, book value of equity and earnings per share are insignificant for loser firms in the post-IFRS period; however, it has a lower coefficient than the coefficient of all firms. This implies that EPS and book value of equity are more value relevant for firms with positive profit.

Table 3. Price regression model 2 (Negative Return as Dummy)

\begin{tabular}{|c|c|c|c|c|c|c|}
\hline \multicolumn{7}{|c|}{$M V_{j t}=\beta_{0}+\beta_{1} B V_{j t}+\beta_{2} E S_{j t}+\beta_{3} B V_{j t} D_{1}+\beta_{4} E S_{j t} D_{1}+\beta_{5} E S_{j t} D_{1}+u_{j t}$} \\
\hline & BV & EPS & $\mathrm{BVD}_{1}$ & $\mathrm{EPSD}_{1}$ & $\mathrm{D}_{1}$ & Adj. $R^{2}$ \\
\hline \multicolumn{7}{|l|}{ Pooled Analysis } \\
\hline Entire Sample & -0.00452 & 190.4 & 0.00449 & -192.1 & -3562 & 0.00721 \\
\hline \multicolumn{7}{|l|}{ Year analysis } \\
\hline Pre-IFRS (2008) & 0.0000134 & $-63.01 * *$ & -0.00000391 & 38.67 & 1.709 & 0.425 \\
\hline 2009 & $-0.0000318 * *$ & 0.391 & 0.0000317 & $-8.855^{* *}$ & $-21.11 * * *$ & 0.550 \\
\hline Post-IFRS (2010) & -0.0557 & 4288.5 & 0.0556 & -4290.3 & -25380.7 & 0.0394 \\
\hline 2011 & 0.0000173 & -7.181 & -0.0000238 & $12.36^{* *}$ & 1.029 & 0.471 \\
\hline 2012 & $-0.0000380^{* *}$ & -2.205 & 0.000051 & -0.332 & -19.88 & 0.264 \\
\hline 2013 & -0.0000707 & -6.823 & 0.000044 & 3.512 & $-33.83 *$ & 0.597 \\
\hline 2014 & $-0.0000341^{* *}$ & 3.41 & 0.000277 & -1.868 & $-73.89 *$ & 0.389 \\
\hline
\end{tabular}

Notes. ${ }^{* * *}$, and $* *$ are statistically significant at $1 \%$ and $5 \%$ respectively. The sample consists of 21 insurance firms listed in the Saudi Stock Exchange with 136 firm year observations for the period 2007-2011. The Variables' Definitions are presented in Table 1.

In the return model, earnings for loser firms are significant in the pre- and post-IFRS period. However, this coefficient is smaller for all the firms, whereas $\Delta$ ET for loser firms are significant in the pre- and post-IFRS periods. It can be concluded that in Saudi Arabia, whatever the accounting standards, the investors are concerned with profitable and loser firms. Therefore, partially hypothesis 2 cannot be rejected. Thus, considering the results, it can be concluded that investors in Saudi Arabia distinguish between profitable and loser firms; so, accounting information is more relevant for loser firms than profitable firms for investors. One can possibly conclude that there is no impact of implementation of IFRS on value relevance, but the profitability may matter. This conclusion supports the results of Al-Sehali and Spear (2004) and Barrak (2011) to some extent.

Table 4. Return regression model 2 (Negative returns as Dummy)

\begin{tabular}{|c|c|c|c|c|c|c|}
\hline \multicolumn{7}{|c|}{$\mathrm{RET}_{\mathrm{jt}}=\alpha_{0}+\alpha_{1} \mathrm{EPS}_{\mathrm{jt}} / \mathrm{P}_{\mathrm{jt}-1}+\alpha_{2}\left(\mathrm{E}_{\mathrm{jt}}-\mathrm{E}_{\mathrm{jt}-1}\right) / \mathrm{P}_{\mathrm{jt}-1}+\alpha_{3}\left(\mathrm{EPS}_{\mathrm{j} t} / \mathrm{P}_{\mathrm{jt}-1}\right) \mathrm{D}_{1}+\alpha_{4}\left(\mathrm{E}_{\mathrm{jt}}-\mathrm{E}_{\mathrm{jt}-1}\right) / \mathrm{P}_{\mathrm{jt}-1} \mathrm{D}_{1}++\alpha_{5} \mathrm{D}_{1}+\mathrm{e}_{\mathrm{jt}}$} \\
\hline & EPS/Pjt-1 & $\Delta \mathrm{ET}$ & EPS/Pjt-1 $D_{1}$ & $\Delta \mathrm{ETD}_{1}$ & $\mathrm{D}_{1}$ & Adj. $R^{2}$ \\
\hline \multicolumn{7}{|l|}{ Pooled Analysis } \\
\hline Entire Sample & $1491557.3 * * *$ & $19.77 * * *$ & -381562 & $-12.98 * * *$ & $46202.1 * * *$ & 0.648 \\
\hline \multicolumn{7}{|l|}{ Year analysis } \\
\hline 2007 & - & $69.96^{* * *}$ & 307770.1 & $-28.53 * *$ & 1977.4 & 0.990 \\
\hline Pre-IFRS (2008) & $344288.9 * *$ & $4.054 *$ & $-78256.8^{* *}$ & $-6.459 * *$ & -5208.1 & 0.809 \\
\hline 2009 & $1008167.8^{* *}$ & $19.13^{* * *}$ & -1081610.5 & -44.34 & -25967.5 & 0.894 \\
\hline Post-IFRS(2010) & $634093.6^{* *}$ & $83.65^{* * *}$ & $-286220.8^{* *}$ & $-86.83 * *$ & $46784 * *$ & 0.790 \\
\hline 2011 & $1494309.9 * *$ & -45.64 & 222911.4 & 8.765 & -12748.7 & 0.624 \\
\hline 2012 & $973773.7^{* * *}$ & 2.06 & -114833 & $-68.92 * * *$ & $-15598.3^{* *}$ & 0.986 \\
\hline 2013 & $1261963.8^{* *}$ & -30.58 & -922078.8 & 48.65 & 26121.3 & 0.925 \\
\hline 2014 & $3975821.9^{* * *}$ & $9.298 *$ & $-3420283.9^{* * *}$ & -12.37 & 21546.9 & 0.826 \\
\hline
\end{tabular}

Notes. ${ }^{* *}$ and $* *$ are statistically significant at $1 \%$ and $5 \%$ respectively. The sample consists of 21 insurance firms listed in Saudi Stock Exchange with 136 firm year observations for the period 2007-2011. The Variables' Definitions are presented in Table 1.

\subsubsection{Size of the Firms}

It is generally assumed that firm size has a significant impact on the value relevance of accounting information. A dummy variable $\left(\mathrm{D}_{2}\right)$ is defined for the size of the firm. Capital of the firm is a proxy of the size; an average is 
calculated; firms with a size greater than the average are considered as large firms and those less than average are considered as small firms. The value of dummy is one for large firms and zero otherwise. The results are depicted in Table 5 and 6.

In the price model, most of the variables are significant in the pre-IFRS period. As shown in Table 5, dummy variable of size, earnings per share and product of book value of equity are significant in the pre-IFRS period, whereas $\mathrm{R}^{2}$ is decreasing in the post-IFRS period. However, in the return model, earnings and size are significantly different from zero in both the periods. Yet, size is significant in pre- and post-IFRS periods. However, $\mathrm{R}^{2}$ declines after the adoption of IFRS, as shown in Table 6 . Book value of equity is significant for large firms for the entire period of the sample. In the return model, the coefficient of change in earnings for large firms is also significant. The results of both models provide evidence that firm size indeed influences value relevance of accounting information in Saudi Arabia in both the periods. These results support the findings of Collins et al. (1997), which argued that size of the firm has influence on the value relevance of accounting information.

Table 5. Price regression model 3 (Size as Dummy) (Dependent Variable MVjt)

\begin{tabular}{|c|c|c|c|c|c|c|}
\hline \multicolumn{7}{|c|}{$\overline{M V_{j t}}=\beta_{0}+\beta_{1} B V_{j t}+\beta_{2} E P S_{j t}+\beta_{3} B V_{j t} D_{2}+\beta_{4} E S_{j t} D_{2}+\beta_{5} E S_{j t} D_{2}+u_{j t}$} \\
\hline \multicolumn{7}{|l|}{ Pooled Analysis } \\
\hline Entire Sample & 0.000884 & 1108.4 & -1091.1 & - & -2630.1 & 0.007 \\
\hline \multicolumn{7}{|l|}{ Year analysis } \\
\hline Pre-IFRS (2008) & $-0.000164 * *$ & $-19.19 *$ & $16.33 * *$ & - & $87.75^{* *}$ & 0.617 \\
\hline 2009 & $-0.0000287 * *$ & -2.009 & 0.548 & - & 5.794 & 0.472 \\
\hline Post-IFRS (2010) & 0.00474 & 13560.7 & -13528.9 & - & -15846.8 & 0.066 \\
\hline 2011 & -0.0000145 & -0.591 & $9.330 * * *$ & - & -5.353 & 0.551 \\
\hline 2012 & -0.0000204 & -0.451 & 4.176 & - & -5.77 & 0.148 \\
\hline 2013 & $-0.000128 * * *$ & 1.454 & $-9.972 * *$ & - & $53.13^{* *}$ & 0.585 \\
\hline 2014 & -0.0000288 & 4.25 & -1.654 & - & 1.721 & 0.211 \\
\hline
\end{tabular}

Notes. ${ }^{* *}$ and $* *$ are statistically significant at $1 \%$ and $5 \%$ respectively. The sample consists of 21 insurance firms listed in the Saudi Stock Exchange with 136 firm year observations for the period 2007-2011. The Variables' Definitions are presented in Table 1.

In the cross-section regression analysis from 2009 to 2014 , the $\mathrm{R}^{2}$ is not consistent. There are a lot of variations in the value of $\mathrm{R}^{2}$, and similarly, in the significance of coefficients. In the return model, the adjusted $\mathrm{R}^{2}$ decreased. However, the results in Table 6 imply that the return model is able to forecast the market behavior of Saudi Arabia to some extent. One can say that independent variables in the return model steadily determine the further changes in returns.

These mixed results may be associated with the particular institutional and environmental factors related to every industry, region, and country (Jeanjean and Stolowy 2008). Landsman et al. (2012) and Daske et al. (2008) commented that the potential of legal enforcement has a significant impact on the relevance of accounting information after the adoption of IFRS. With reference to the context of the Saudi market, Alsalman (2003) reported similar results, arguing that institutional factors influence the value relevance of accounting information in Saudi Arabia.

Table 6. Return regression model 3 (Size as Dummy) (Dependent Variable RETjt)

\begin{tabular}{|c|c|c|c|c|c|c|}
\hline \multicolumn{7}{|c|}{$\operatorname{RET}_{\mathrm{jt}}=\alpha_{0}+\alpha_{1} \mathrm{EPS}_{\mathrm{j} t} / \mathrm{P}_{\mathrm{jt}-1}+\alpha_{2}\left(\mathrm{E}_{\mathrm{jt}}-\mathrm{E}_{\mathrm{jt}-1}\right) / \mathrm{P}_{\mathrm{jt}-1}+\alpha_{3}\left(\mathrm{EPS}_{\mathrm{j} t} / \mathrm{P}_{\mathrm{jt}-1}\right) \mathrm{D}_{2}+\alpha_{4}\left(\mathrm{E}_{\mathrm{jt}}-\mathrm{E}_{\mathrm{jt}-1}\right) / \mathrm{P}_{\mathrm{jt}-1} \mathrm{D}_{2}++\alpha_{5} \mathrm{D}_{1}+\mathrm{e}_{\mathrm{jt}}$} \\
\hline & EPS/Pjt-1 & $\Delta \mathrm{ET}$ & EPS/Pjt-1D 2 & $\Delta \mathrm{ETD}_{2}$ & $\mathrm{D}_{2}$ & Adj. $R^{2}$ \\
\hline \multicolumn{7}{|l|}{ Pooled Analysis } \\
\hline Entire-Sample & $456545.2 * * *$ & 1.175 & $1898849.1 * * *$ & 4.438 & 15041.6 & 0.766 \\
\hline \multicolumn{7}{|l|}{ Year analysis } \\
\hline 2007 & $724470.4 * * *$ & $32.38 * * *$ & $-1541606.0 * * *$ & $46.13 * * *$ & $-7630.7^{* * *}$ & 0.999 \\
\hline Pre-IFRS (2008) & $334155.8 * * *$ & $-2.566^{*}$ & $969688.1 * * *$ & $1.728^{*}$ & $-6008.9^{*}$ & 0.976 \\
\hline 2009 & 537055.6 & 1.78 & $1361147.9^{*}$ & 7.312 & -14194.5 & 0.897 \\
\hline Post-IFRS (2010) & $493716.9 * * *$ & $-2.072 * *$ & $-155300.3^{* *}$ & $85.02 *$ & $-10977.2^{*}$ & 0.813 \\
\hline 2011 & 556607.9 & -6.574 & $2589083.2 * * *$ & -28.69 & $-65630.2 *$ & 0.885 \\
\hline 2012 & $682500.3^{*}$ & -2.013 & $876985.4^{*}$ & -16.77 & 26165.5 & 0.900 \\
\hline 2013 & $361790.4 * * *$ & $8.942 * * *$ & $-1771501.1 * * *$ & $32.49 * * *$ & $263981.4^{* * *}$ & 0.998 \\
\hline 2014 & $587852.8 * * *$ & -0.632 & $6752020.9^{* * *}$ & -0.997 & $-55157.2 * * *$ & 0.992 \\
\hline
\end{tabular}

Notes. $* * *$ and $* *$ are statistically significant at $1 \%$ and $5 \%$ respectively. The sample consists of 21 insurance firms listed in the Saudi Stock Exchange with 136 firm year observations for the period 2007-2011. The Variables' Definitions are presented in Table 1. 


\section{Conclusion}

The objective of this study was to examine the impact of the adoption of IFRS on the value relevance of book values of equity and earnings. Simultaneously, it also examined the impact of the size of a firm and negative vs. positive earnings on value relevance. The dataset of this study comprised 21 firms, with 136 firm year observations covering the period 2007-2014. For the empirical analysis, this study employed the Easton and Harris (1991) and Feltham and Ohlson (1995) models.

It has been observed from the results that value relevance of book value of equity has decreased in the post-IFRS period. However, in the return model, the value relevance of earnings has a significant impact in the pre- and the post-IFRS periods. This might be due to the substitutability between the earnings and book value of equity. Only size of the firm shows value relevance in Saudi insurance companies in the pre- and post-IFRS period, whereas change in earnings of large firms is more value relevance. Negative earnings also have value relevance in the Saudi market in both of the periods.

This study observed mixed results. This could be due to certain indigenous institutional factors (regulatory accounting framework and investor protection) and legal environment that are specific to Saudi Arabia's economy. Still, this market is not fully mature, and the investors and other stakeholders may be more concerned with their personal incentives and benefits than with following the market regulations. Moreover, the social, cultural, and religious environments also have their impact on the investor's decision, which tempers the impact of accounting information. Alsalman (2003) and Al-Sehali and Spear (2004) reported similar interpretations regarding the possible impact of environmental constituents in relation to regulation, monitoring system, and demand for accounting information.

Overall, it can be concluded that the results generally indicate that positive vs. negative earnings and firm size affect the value relevance of accounting information in Saudi Arabia. It is accepted that the financial market will be graduated through a passage of time. For the betterment of the system of accounting information in Saudi economy, it is suggested that authorities of this country should educate investors through different tools and guide them with the help of market gurus. These results should be aligned with consciousness of the uncertainty that prevailed all over the world in the financial markets during the sample period, which could have had an effect on the results of this study.

\section{References}

Alkhatani, S. (2012). The relevance of IFRSs to less developed economies: Challenges and opportunities, Saudi Arabia as a case study. Journal of Administrative and Economics Sciences, 5(2), 21-45.

Almotairy, O. S., \& Alsalman, A. M. (2011).Challenges facing adopting IFRS in Saudi Arabia. Paper presented at the 1st Annual Journal of International Accounting Research Conference, Xiamen, China.

Almotairy, O. S., \& Stainbank, L. J. (2014). Compliance with international education standards in Saudi Arabia: policy and education implication. Journal of Business Studies Quarterly, 5(4), 5-20.

Alnodel, A. A. (2015). Does Mandatory IFRS Adoption Improve Market Efficiency in Emerging Stock Markets? Evidence from Saudi Arabia. Global Review of Accounting and Finance, 6(2), 1-15.

Alnodel, A. A. (2016). The effect of the adoption of international financial reporting standards on capital market integration in the Gulf cooperation council countries. Risk Governance and Control: Financial Markets \& Institutions, 6(4), 464-474.

Alsalman, H. M. (2003). The value relevance of accounting numbers and the implications for international accounting standards harmonization: Evidence from Saudi Arabia and Kuwait (Unpublished doctoral dissertation). Florida Atlantic University, Florida, USA.

Al-Sehali, M., \& Spear, N. (2004). The decision relevance and timeliness of accounting earnings in Saudi Arabia. The International Journal of Accounting, 39(2), 197-217. https://doi.org/10.1016/j.intacc.2004.02.004

Alsuhaibani, A. (2012). The expected impact of IFRS adoption on Saudi Arabia base on lessons from other countries: A focus on the telecommunication business. Procedis-Social and Behavioral Sciences, 62, 1190-1198. https://doi.org/10.1016/j.sbspro.2012.09.204

Amir, E., Harris, T. S., \& Venuti, E. K. (1993). A comparison of value relevance of US versus non-US GAAP accounting measures using form 20-F reconciliations. Journal of Accounting Research, 31, 230-264. http://www.jstor.org/stable/2491172

Ball, R., \& Brown, P. (1968). An empirical evaluation of accounting income numbers. Journal of Accounting 
Research, 6(2), 159-178. http://dx.doi.org/10.2307/2490232

Barrak, T. (2011). Value relevance and predictive ability of financial statement information: the case of Saudi Arabia (Unpublished doctoral dissertation).University of Portsmouth, Portsmouth, UK.

Barth, M. E., Beaver, W. H., \& Landsman, W. R. (2001). The relevance of the value relevance literature for financial accounting standard setting: another view. Journal of Accounting and Economics, 31(1/2/3), 77-104. https://doi.org/10.1016/S0165-4101(01)00019-2

Barth, M. E., Landsman, W. R., \& Lang, M. H. (2008). International Accounting Standards and Accounting Quality. Journal of Accounting Research, 46(3), 467-498. https://doi.org/10.1111/j.1475-679X.2008.00287.x

Bartov, E., Goldberg, S. R., \& Kim, M. (2005). Comparative value relevance among German, US, and international accounting standards: A German stock market perspective. Journal of Accounting and, Auditing and Finance, 20(2), 95-119. Retrieved from https://ssrn.com/abstract=316525

Benayed, M. R., \& Abaoud, E. (2006). Value relevance of accounting earnings and the information contents: empirical evidence in Tunisian stock exchange. Retrieved from https://ssrn.com/abstract $=940791$

Brimble, M., \& Hodgson, A. (2007). On the intertemporal value relevance of conventional financial accounting in Australia. Accounting and Finance, 47(4) 599-622. Retrieved from https://ssrn.com/abstract=1067089

Callao, S., Jarne, J. I., \&La'inez, J. A. (2007). Adoption of IFRS in Spain: effect on the comparability and relevance of financial reporting. Journal of International Accounting, Auditing and Taxation, 16(2), 148-178. https://doi.org/10.1016/j.intaccaudtax.2007.06.002.

Chandrapala, P. (2013). The value relevance of earnings and book value: the importance of ownership concentration and firm size. Journal of Competitiveness, 5(2), 98-107. https://doi.orgl10.7441/joc.2013.02.07

Chen, J., Chen, S., \& Su, X. (2001). Is accounting information value-relevant in the emerging Chinese stock market? Journal of International Accounting Auditing and Taxation, 10(1), 1-22. https://doi.org/10.1016/S1061-9518 (01)00033-7

Clarkson, P., Hanna, J. D., Richardson, G. D., \& Thompson, R. (2011). The impact of IFRS adoption on the value relevance of book value and earnings. Journal of Contemporary Accounting \& Economics, 7(1), 1-17. https://doi.org/10.1016/j.jcae.2011.03.001

Collins, D. W., Maydew, E. L., \& Weiss, L. S. (1997). Changes in the value-relevance of earnings and book values over the past forty years. Journal of Accounting \& Economics, 24(1), 143-181. https://doi.org/10.1016/S0165-4101(97)00015-3

Daske, H., Hail, L., Leuz, C., \& Verdi, R. (2008). Mandatory IFRS reporting around the world: early evidence on the economic consequences. Journal of Accounting Research, 46(5), 1085-1142. https://doi.org/10.1111/j.1475-679X.2008.00306.x

Easton, P. D., \& Harris, T. S. (1991). Earnings as an Explanatory Variable for Returns. Journal of Accounting Research, 29(1), 19-36. Retrieved from http://www.jstor.org/stable/2491026.

Easton, P. D., \& Sommers, G. A. (2003). Scale and the scale effect in market-based accounting research. Journal of Business Finance and Accounting, 30(1-2), 25-35. https://doi.org/10.1111/1468-5957.00482

Feltham, G. A., \& Ohlson, J. A. (1995).Valuation and clean surplus accounting for operating and financial activities. Contemporary Accounting Research, 11(2), 689-732. Retrieved from https://10.1111/j.1911-3846.1995.tb00462.x

Gjerde, Ø., Knivsflå, K., \& Sættem, F. (2011). The value-relevance of financial reporting in Norway 1965-2004.Scandinavian Journal of Management, 27(1), 113-128. https://doi.org/10.1016/j.scaman.2010.08.001

Halonen, E., Pavlovic, P.,\& Persson, R. (2013).Value relevance of accounting information and its impact on stock prices: evidence from Sweden. Journal of Contemporary accounting \& Economics, 9(1), 47-59.

Hayn, C. (1995). The information content of losses. Journal of Accounting and Economics, 20(2), 125-153. https://doi.org/10.1016/0165-4101(95)00397-2

Holthausena, R. W., \& Watts, R. L. (2001). The relevance of the value-relevance literature for financial accounting standard setting. Journal of Accounting and Economics, 31(1-3), 3-75. 
https://doi.org/10.1016/S0165-4101(01)00029-5

Jeanjean, T., \& Stolowy, H. (2008). Do accounting standards matter? an exploratory analysis of earnings management before and after IFRS adoption. Journal of Accounting and Public Policy, 27(6), 480-494. https://doi.org/10.1016/j.jaccpubpol.2008.09.008

Klimczak, K. M. (2011). Market reaction to mandatory IFRS adoption: evidence from Poland. Accounting and Management Information Systems, 10(2), 228-248. https://ssrn.com/abstract=1752809.

Kousenidis, D. V., Ladas, A. C., \& Negakis, C. I. (2010).Value relevance of accounting information in pre-post-IFRS accounting periods. European Research Studies, 8(1), 145-154. Retrieved from https://ideas.repec.org/a/ers/journl/vxiiiy2010i1p143-152.html.

Landsman, W. R., Maydewa, E. L., \& Thornmock, J. R. (2012). The information content of annual earnings announcement and mandatory adoptions of IFRS. Journal of Accounting and Economics, 53(1\&2), 34-54. https://doi.org/10.1016/j.jacceco.2011.04.002

Nissim, D. (2010). Analysis and valuation of insurance companies-industry study number two. Centre for Excellence in Accounting \& Security Analysis, Columbia Business School. Retrieved from http://www8.gsb.columbia.edu/ceasa/research

Nurunnabi, M. (2017). IFRS and Saudi accounting standards: a critical investigation. International Journal of Disclosure and Governance, 14(3), 191-206. https://doi.org/10.1057/s41310-017-0020-0

Ohlson, J. (1995). Earnings, book values, and dividends in equity valuation. Contemporary Accounting Research, 11(2), 661-687. https://doi.org/10.1111/j.1911-3846.1995.tb00461

Ota, K. (2001).The impact of valuation models on value-relevance studies in accounting: a review of theory and evidence. Retrieved from https://ssrn.com/abstract $=280873$

Shamki, D., \& Raman, A. A. (2012). Value relevance of earnings and book value: Evidence from Jordan. International Journal of Business and Management, 7(3), 133-141. http://dx.doi.org/10.5539/ijbm.v7n3p133

Soderstrom, N. S., \& Sun, K. I. (2007). IFRS adoption and accounting quality: a review. European Accounting Review, 16(4), 675-702. Retrieved from https://ssrn.com/abstract=1008416.

Tarca, A. (2012). The case for global accounting standards: arguments and evidence. Retrieved from Retrieved from https://ssrn.com/abstract $=2204889$

\section{Copyrights}

Copyright for this article is retained by the author (s), with first publication rights granted to the journal.

This is an open-access article distributed under the terms and conditions of the Creative Commons Attribution license (http://creativecommons.org/licenses/by/4.0/). 